\title{
Pituitary hormone mRNA expression in European sea bass Dicentrarchus labrax in seawater and following acclimation to fresh water
}

\author{
Stamatis Varsamos, Benoît Xuereb, Thérèse Commes ${ }^{\mathbf{1}}$, Gert Flik ${ }^{\mathbf{2}}$ and Céline Spanings-Pierrot \\ Adaptation Ecophysiologique et Ontogenèse, UMR 5171, GPIA, Université Montpellier II, Place Eugène Bataillon, CC092, 34095 Montpellier Cedex 05, France \\ ${ }^{1}$ IGH/UPR, CNRS 1142, 141 rue de la Cardonille, 34396 Montpellier Cedex 05, France \\ ${ }^{2}$ Department of Animal Physiology, Faculty of Science, Toernooiveld 1, 6525 ED Nijmegen, The Netherlands \\ (Requests for offprints should be addressed to S Varsamos; Email: varsamos@univ-montp2.fr)
}

\begin{abstract}
The mRNA expression of pituitary prolactin (prl), growth hormone (gh), somatolactin (sl), proopiomelanocortin (pomc), and gonadotropins (gthI and gthII) was quantified by real-time PCR, in sea bass, Dicentrarchus labrax, adapted for 1 month to seawater (SW) or freshwater (FW). In addition, IGF-I (igfl) mRNA expression in liver and branchial $\mathrm{Na}^{+} / \mathrm{K}^{+}$-ATPase activity were determined. L17 ribosomal protein $(\mathrm{rpL} 17)$ and elongation factor $1 \alpha($ efl $\alpha)$ were validated as reference genes in real-time PCR in the experimental context. The real-time PCR assays were validated for the different hormone genes considered. Expression of pituitary pomc, gthI, gthII, gh, and
\end{abstract}

liver igfl was not significantly different between FW and SW fish. Pituitary prl was $4 \cdot 5$-fold higher in FW than in SW, whereas pituitary sl was $1 \cdot 8$-fold higher in SW- compared with FW-adapted fish. Gill $\mathrm{Na}^{+} / \mathrm{K}^{+}$-ATPase specific activity was 2.3-fold higher in FW sea bass compared with SW fish. Plasma cortisol levels were 6.5-fold lower in SW- than in FW-adapted specimens. The results are discussed in relation to the osmoregulatory strategy of this euryhaline SW species, which displays features that do not fit present models based on salmonids and FW euryhaline teleosts.

Journal of Endocrinology (2006) 191, 473-480

\section{Introduction}

Endocrine control of osmoregulation has been studied only in a limited number of teleostean species, with an emphasis on salmonids. These studies underline the importance of pituitary hormones, such as prolactin (Hirano et al. 1987, Manzon 2002) or growth hormone (i.e. the gh/igfl axis; Sakamoto et al. 1993, McCormick 2001) in the adaptation to gradual or rapid salinity changes; also in the ontogenetic acquisition of salinity tolerance, these hormones play a pivotal role (Bouf 1993, Varsamos et al. 2005). The hormones target ionocytes (Pisam \& Rambourg 1991, Sakamoto et al. 2001) and the ion transporters therein (mainly $\mathrm{Na}^{+} / \mathrm{K}^{+}$-ATPase), in osmoregulatory tissues (Marshall 1995, McCormick 1995, Manzon 2002). They also affect mechanisms involved in the control of water balance (Fuentes \& Eddy 1997).

The European sea bass (Dicentrarchus labrax Linnaeus 1758) is a marine teleost fish which has aroused significant socioeconomic and scientific interest, especially around the Mediterranean Sea (Pickett \& Pawson 1994). Its remarkably strong euryhalinity - it thrives in fresh water $(\mathrm{FW})$, seawater (SW) and even concentrated SW - makes this species an excellent model to study adaptive ecophysiology. In previous works, we have determined the tolerance of sea bass to hypersaline SW (Varsamos 2002), explored the fundamental ultrastructural and physiological bases for its euryhalinity (Varsamos et al. 2002b) and described the development of its osmoregulatory capacity throughout post-embryonic development (Varsamos et al. 2001, 2002a, 2004). Interestingly, the osmoregulatory strategy of sea bass during adaptation to FW differs from that of other euryhaline teleosts. In fact, when sea bass moves from SW to FW, its branchial ionocytes undergo morphological changes (Varsamos et al. 2002b) that remind of phenomena normally seen when euryhaline fish move oppositely, i.e. from FW to SW. Indeed, these changes are thus opposite to those seen in salmonids that return to FW for spawning (Pisam \& Rambourg 1991). Hence, an investigation into the endocrine control of the osmoregulatory processes could further our understanding of the adaptive strategy employed by this marine species to enter FW habitats.

To date, mainly semi-quantitative approaches have been used to monitor the gene expression in fish and only limited data have been generated by real-time quantitative PCR, a powerful technique for profiling gene expression (Bustin et al. 2005). Although semi-quantitative methods are reliable, they are generally complex and their results cannot be easily compared with those obtained in other species or with those of independent experiments. Implementation of standard real-time PCR protocols should enhance developments in 
comparative physiology. To study the involvement of pituitary hormones known to be involved in the adaptation to different salinities, we made a quantitative profile of a series of pituitary mRNAs by real-time quantitative PCR of sea bass adapted for 1 month to SW or FW. We considered hormones with established effects on osmoregulatory processes in teleosts, viz. prolactin (prl), growth hormone (gh), somatolactin (sl), proopiomelanocortin (pomc); the gonadotropins (gthI and II) were considered as well, as reproduction is known to compromise osmoregulation and vice versa. Liver insulin-like growth factor-I (igfl) mRNA was also assessed as a second parameter of the gh/igfl axis; the liver is generally considered as the main source of circulating igfl (Plisetskaya 1998), although other peripheral sites of production are known (Sakamoto \& Hirano 1993). Plasma cortisol (widely considered the SW-adapting hormone) levels were also determined. Branchial $\mathrm{Na}^{+} / \mathrm{K}^{+}$-ATPase activity was assayed to determine potential correlations between pituitary hormone expression and activity of this key enzyme in ion transport and osmoregulation.

\section{Materials and Methods}

\section{Fish and experimental design}

Fish were kept in the aquaculture facilities of the Station Biologique de Sète (Hérault, France) in early 2004. Thirty fish (weight: $250 \pm 50 \mathrm{~g}$ ) of identical genetic origin and reared in SW from hatching were randomly split into two batches of 15 fish transferred to two $2 \mathrm{~m}^{3}$ tanks containing SW (salinity: $35 \%$ ). In one tank, salinity was reduced by the addition of dechlorinated FW to reach $0 \cdot 3 \%$ after 1 week. Temperature in both tanks ranged between 11 and $14{ }^{\circ} \mathrm{C}$. The fish were fed commercial pellets, at a ration of $2 \%$ of the estimated body weight per day. They were starved $24 \mathrm{~h}$ before sampling (routine precaution before fish handling).

\section{Sampling, RNA isolation, and $c D N A$ synthesis}

After 1 month of adaptation, ten fish from each salinity were randomly netted and rapidly sacrificed by decapitation. Pituitary glands were dissected on ice, placed in individual vials containing RNAlater (Ambion, Cambridgeshire, UK) to preserve RNA for molecular analyses and frozen at $-20^{\circ} \mathrm{C}$ until further processing; the liver was rapidly taken out and small portions $\left(1-2 \mathrm{~mm}^{3}\right)$ treated similarly.

A commercial kit (SV Total RNA Isolation System; Promega), which combines the protective properties of guanidine thiocyanate and $\beta$-mercaptoethanol to inactivate RNases and includes a DNase treatment to remove contaminating DNA, was used to extract total RNA from individual pituitary and liver samples. RNA was finally eluted with $15 \mu \mathrm{l}$ nuclease-free $\mathrm{H}_{2} \mathrm{O}$ and stored at $-80^{\circ} \mathrm{C}$.

RNA concentration, integrity, and purity of each sample were determined with an RNA Bioanalyzer 2100 (Agilent
Technologies, Palo Alto, CA, USA). The method employs electrophoretic analysis with microfluidics RNA Nano-chips (Agilent, USA) and fluorescence monitoring. For each total RNA sample, the concentration was measured in duplicate on $1 \mu \mathrm{l}$ aliquots. Electrophoresis was conducted inside the Agilent Bioanalyzer and results were analyzed with Agilent 2100 Bio Sizing software.

For synthesis of first strand cDNA, an 'alien' gene (mRNA of chlorophyll A/B-binding protein (CAB) from Arabidopsis thaliana) was used to calibrate reverse transcription (VarletMarie et al. 2004): $0 \cdot 6 \mu \mathrm{g}$ total RNA and $1 \mu \mathrm{l} \mathrm{CAB}\left(4 \cdot 10^{8}\right.$ copies; Stratagene) were then reverse transcribed with oligo-dT as primer and SuperScript II reverse transcriptase (SuperScript II first-strand synthesis kit, Invitrogen). The resultant cDNAs were checked by conventional PCR and stored at $-20^{\circ} \mathrm{C}$.

\section{Primer design for target and reference genes}

Sequences available on the GenBank database allowed primer design for most of the genes used in the present work (Table 1). Two to four primer sets (purchased from Sigma Genosys, UK) were designed for each gene with Primer 3 software (http://frodo.wi.mit.edu/cgi-bin/primer3/primer3_www.cgi) and different PCR conditions were tested for each couple of primers to determine the most efficient set for PCR and real-time quantitative PCR. Control or invariant internal 'house-keeping' genes were necessary for the global normalization of the quantification by real-time PCR. The candidate control genes were the L17 ribosomal protein (rpL17), a sea bass house-keeping gene validated previously (Varsamos et al. 2003) and elongation factor $1 \alpha$ $($ ef $1 \alpha)$. To determine sea bass ef $1 \alpha$-specific primers, PCR was performed on cDNA obtained from sea bass pituitary RNA with degenerate primers designed on the basis of consensus ef1 $\alpha$ sequences (GenBank; http://www.ncbi.nlm.nih.gov/ Genbank/index.html).

After an initial denaturing step at $95^{\circ} \mathrm{C}$ for $2 \mathrm{~min}$, PCR was performed on $1 \mu \mathrm{l}$ template cDNA during 40 cycles of $95^{\circ} \mathrm{C}$ for $30 \mathrm{~s}, 50{ }^{\circ} \mathrm{C}$ for $30 \mathrm{~s}$, and $72{ }^{\circ} \mathrm{C}$ for $1 \mathrm{~min}$. A final extension step at $72{ }^{\circ} \mathrm{C}$ for $2 \mathrm{~min}$ was carried out. PCR products were analyzed by electrophoresis on a $1.5 \%$ agarose/ethidium bromide gel, cloned and sequenced.

\section{Quantification of target and reference gene expression}

Quantification of $p r l, g h$, sl, pomc, gthI, and gthII gene expression on sea bass cDNAs in pituitary gland, of igfl expression in liver and of rpL17 and ef1 $\alpha$ in both pituitary gland and liver, was carried out by means of real-time quantitative PCR using a Light Cycler (Roche) according to Varsamos et al. (2003).

Dilutions of a reference sample were used to obtain the calibration curve, demonstrating a linear relationship between threshold cycle $\left(C_{t}\right)$ and $\log _{10}$ of template availability. Ten microliter reactions were run containing $2 \mu \mathrm{l}$ PCR Mix 
Table 1 Primers sequences for quantification of sea bass (Dicentrarchus labrax) hormone expression by real-time quantitative PCR $(\mathrm{W}=\mathrm{A} / \mathrm{T})$

\begin{tabular}{|c|c|c|c|c|}
\hline & Primers & Primers sequences $\left(5^{\prime}-3^{\prime}\right)$ & $\begin{array}{l}\text { Expected } \\
\text { size }(b p)\end{array}$ & $\begin{array}{l}\text { Gene sequence references/ } \\
\text { accession no }\end{array}$ \\
\hline \multicolumn{5}{|l|}{ Genes } \\
\hline \multirow[t]{2}{*}{ Prolactin (prl) } & PRL DL2-F & GСТСТGАСАСАСТGСАСТСС & 219 & Doliana et al. (1994) \\
\hline & PRL DL2-R & AGGATTACAAGGGGGTCTCG & & X78723 \\
\hline \multirow[t]{2}{*}{ Growth hormone $(g h)$} & $\mathrm{GH}_{\mathrm{DL} 1-\mathrm{F}}$ & GACAAGCACGAGACACAACG & 195 & Doliana et al. (1992) \\
\hline & $\mathrm{GH}_{\mathrm{DL} 1-\mathrm{R}}$ & CTGTCAGGGAACATCTCTGC & & \\
\hline \multirow[t]{2}{*}{ Proopiomelanocortin (pomc) } & Dlp-F & AAGCCTGTTGGACGAAAGC & 191 & Varsamos et al. (2003) \\
\hline & Dlp-R & GAGCCATCСТTCTTCTCGTG & & AY 691808 \\
\hline \multirow[t]{2}{*}{ Somatolactin $(s l)$} & $\mathrm{SL}_{\mathrm{DL} 1-\mathrm{F}}$ & САТСАССАAAGССТTACСC & 300 & Company et al. (2000) \\
\hline & SL DL1-R & GGCACATCATACTGGAATAGGC & & AJ277390 \\
\hline \multirow[t]{2}{*}{ Gonadotropin I (gthI) } & GTHI DL2-F & GTGCTACCACGAGGATCTGG & 208 & Mateos et al. (2003) \\
\hline & GTHI DL2-R & GGGTATGTCTCCAGGAAAGC & & AF543314 \\
\hline \multirow[t]{2}{*}{ Gonadotropin II (gthIl) } & GTHII DL1-F & CAGAGTGATGTTCCCCTTGG & 203 & Mateos et al. (2003) \\
\hline & GTHII DL1-R & TGACAGGGTCCTTAGTGATGC & & AF543315 \\
\hline \multirow[t]{2}{*}{ Insulin-like growth factor I (igfl) } & IGFI DL1-F & CGCTGCAGTTTGTGTGTGG & 207 & AY 800248 \\
\hline & IGFI DL1-R & CTCTTGGCATGTCTGTGTGG & & \\
\hline \multirow[t]{2}{*}{ Elongation factor $1 \alpha(e f 1 \alpha)$} & EF1 DL1-F & GGCTGGTATCTCCAAGAACG & 239 & Present study \\
\hline & EF1 DL1-R & GTCTCCAGCATGTTGTCWCC & & \\
\hline \multirow[t]{2}{*}{ Ribosomal protein L17 (rpL17) } & DlrpL17-F & CTGGCTTGCСТTTСТTGАCT & 201 & AF139590 \\
\hline & DlrpL17-R & GAGGACGTGGTGGTTCATCT & & \\
\hline \multirow[t]{2}{*}{ Chlorophyll A/B-binding protein (CAB) } & $\mathrm{CAB}-\mathrm{F}$ & GCATTTGTTGAGCACCAGAG & 259 & Varlet-Marie et al. (2004) \\
\hline & CAB-R & TATCGCCAATGTTGTTGTGC & & \\
\hline
\end{tabular}

All except the last (i.e. $C A B$ ) gene sequence references are from sea bass. Primers codes are arbitrary.

(containing SYBR Green and Taq DNA polymerase, purchased from Roche), $0.5 \mu$ l of each primer $(20 \mu \mathrm{M})$, $6 \mu \mathrm{l}$ nuclease-free $\mathrm{H}_{2} \mathrm{O}$ and $1 \mu \mathrm{l}$ template DNA (measured in duplicate). The thermal profile used for real-time PCR consisted of a step at $95^{\circ} \mathrm{C}$ for $10 \mathrm{~min}$ and 40 cycles of denaturing at $95^{\circ} \mathrm{C}$ for $15 \mathrm{~s}$, annealing at $62{ }^{\circ} \mathrm{C}$ for $4 \mathrm{~s}$ and elongation at $72^{\circ} \mathrm{C}$ for $8 \mathrm{~s}$. After the last cycle, temperature in the Light Cycler chamber increased to $95^{\circ} \mathrm{C}$ and then decreased to $62{ }^{\circ} \mathrm{C}$ for $30 \mathrm{~s}$. Then it was increased gradually to $95^{\circ} \mathrm{C}$ to obtain the melting curves of the amplified fragments. Absence of non-specific PCR products and primer dimers was checked by the melting curve analysis and electrophoresis on $8 \%$ acrylamide/SYBR Green gel.

Quantification and analysis of the results were performed using Light Cycler Relative Quantification Software 1.0 (Roche) and calculations were done according to Rasmussen (2001). Both 'second derivative' and 'fit point' methods were applied to the data set. $C_{t}$ values from target genes were normalized to $\mathrm{CAB} C_{\mathrm{t}}$ values for each individual sample. The quantification of the gene expression is presented both in terms of absolute number of copies of mRNA per microgram total RNA and relative to the expression of house-keeping genes.

\section{Plasma cortisol levels}

Plasma concentrations of cortisol were determined in triplicate by RIA according to Arends et al. (1998) using a commercial antiserum (Bioclinical Services Ltd, Cardiff, UK). The cortisol antibody cross-reactivity with 11-deoxycortisol, cortisone acetate, cortisone, and $17 \mathrm{a}-\mathrm{OH}$-progesterone was 5·9, 0·16, $2 \cdot 6$, and $0 \cdot 4 \%$ respectively. Standards and samples $(10 \mu \mathrm{l})$ in RIA buffer (phosphate-EDTA buffer containing 0-1\% 8-anilino-1naphthalenesulfonic acid and $0 \cdot 1 \%(\mathrm{w} / \mathrm{v})$ bovine $\gamma$-globulin) were incubated with $100 \mu \mathrm{l}$ antiserum (in RIA buffer containing $0 \cdot 2 \%$ normal rabbit serum) for $4 \mathrm{~h}$. Samples were incubated overnight with $100 \mu$ lodinated cortisol (2000 disintegration per minute; Amersham Nederland BV, 's Hertogenbosch, The Netherlands). Bound and free hormone were separated by adding $1 \mathrm{ml}$ ice-cold precipitation buffer (phosphate-EDTA buffer containing $2 \%(\mathrm{w} / \mathrm{v})$ BSA and $5 \%(\mathrm{w} / \mathrm{v})$ polyethylene glycol). The tubes were centrifuged at $4{ }^{\circ} \mathrm{C}(2000 \mathrm{~g}, 20 \mathrm{~min})$, the supernatants removed and counted in a gamma counter (LKB Wallac, Finland).

\section{Gill $\mathrm{Na}^{+} / \mathrm{K}^{+}$-ATPase activity}

The first right side gill arch was removed and rinsed in a solution ( $\mathrm{pH} 7 \cdot 4$ ) containing $300 \mathrm{mM}$ sucrose, $20 \mathrm{mM}$ $\mathrm{Na}_{2}$ EDTA and $100 \mathrm{mM}$ imidazol (Zaugg 1982), placed in tubes containing the same solution and stored at $-20^{\circ} \mathrm{C}$ until use. During the whole procedure, samples were kept on ice.

Stored samples were thawed at room temperature and briefly centrifuged. The preservation medium was then removed, branchial arch cartilage discarded and $2 \mathrm{ml}$ isotonic isolation medium (IIM: $250 \mathrm{mM}$ sucrose, $5 \mathrm{mM} \mathrm{MgCl}_{2}$ and 5 mM Hepes; pH 7.4) were added in each tube. Samples were then homogenized in a glass potter homogenization device and the homogenate obtained was subsequently centrifuged at $3000 \mathrm{~g}$ for $5 \mathrm{~min}$ at $4{ }^{\circ} \mathrm{C}$ to eliminate debris. The supernatant containing the plasma membrane fragments was transferred to new tubes. During the extraction procedure, samples were maintained at $4{ }^{\circ} \mathrm{C}$ on ice. 
Enzyme specific activity was expressed per milligram protein. To this end, protein was determined by a colorimetric method (Bio-Rad) using BSA as reference. $\mathrm{Na}^{+} / \mathrm{K}^{+}$-ATPase specific activity was assessed as the difference of ATP hydrolysis in the presence of $\mathrm{Na}^{+}, \mathrm{K}^{+}, \mathrm{Mg}^{2+}$, and ATP, and that in the same medium without $\mathrm{K}^{+}$, but with an optimal concentration of ouabain $(1 \mathrm{mg} / \mathrm{ml}$; Flik et al. 1983). The amount of phosphate released was assessed colorimetrically against a certified standard (Sigma). The enzyme specific activity was expressed in $\mu \mathrm{mol} \mathrm{P}_{\mathrm{i}} / \mathrm{h}$ per mg protein.

\section{Statistical analysis}

From each of the FW and SW tanks, ten fish were sampled and analyzed, as described above. In two of the FW-adapted fish, pituitary total RNA was too low following RNA extraction, reducing $n$ to 8 . Data are expressed as mean \pm s.D. and were checked for normal distribution. Comparisons in gene expression and gill $\mathrm{Na}^{+} / \mathrm{K}^{+}$-ATPase activity between SW and FW fish were statistically analyzed by Student's $t$-test; statistical significance was accepted when $P<0 \cdot 05$.

\section{Results}

Normalization and high quality RNA are crucially important to produce reliable quantification by real-time PCR. Measurements of RNA concentrations using the Agilent 2100 Bioanalyzer confirmed the quality of RNA isolation procedure and allowed the same amount of RNA to be used for reverse transcription (RT) of the individual samples. The 'alien' gene used in this study $(\mathrm{CAB})$ allowed normalization of the results of the RT by correction for target gene $C_{\mathrm{t}}$ values with the $C_{\mathrm{t}}$ values of the $\mathrm{CAB}$ for each individual sample. Quantification of expression data obtained by either the 'second derivative' or the 'fit point' methods resulted in a similar outcome; data obtained by the 'second derivative' method are presented here. Abundance of mRNA is expressed in terms of number of copies per microgram RNA as well as in values relative to the house-keeping genes.

The efficiencies of the real-time PCR for all the genes examined in this study ranged between 1.804 and 1.996 (Table 2).

The house-keeping genes tested in the present work were validated as controls for experiments involving sea bass adapted to $\mathrm{SW}$ and $\mathrm{FW}$, since no significant variation in their expression was found, either in pituitary glands or in liver, independent of ambient salinity. In terms of number of copies per microgram RNA (Fig. 1), expression levels of rpL17 in the pituitary of SW and FW fish were $962000 \pm 40485$ and $1192671 \pm 136999$ respectively $(P=0 \cdot 14)$. No differences were found in $\mathrm{rpL} 17$ expression levels in liver (approximately 600000 copies per microgram RNA; $P=0 \cdot 8$ ). Expression levels of ef1 $\alpha$, in terms of the number of copies per microgram RNA, in the pituitary of SW and FW fish were $1094934 \pm 82131$ and $1488963 \pm$ 239786 respectively $(P=0 \cdot 15$; Fig. 1$)$.
Table 2 Efficiencies of real-time quantitative PCR applied for quantification of sea bass (Dicentrarchus labrax) hormone expression in fish maintained in SW and FW

\section{Efficiencies}

$\begin{array}{ll}\begin{array}{l}\text { Genes } \\ \text { ef1 } \alpha\end{array} & \\ \text { rpL17 (pituitary) } & 1 \cdot 953 \\ \text { prl } & 1 \cdot 883 \\ \text { gh } & 1 \cdot 884 \\ \text { sl } & 1 \cdot 961 \\ \text { pomc } & 1 \cdot 907 \\ \text { gthl } & 1 \cdot 804 \\ \text { gthll } & 1 \cdot 958 \\ \text { igfl (liver) } & 1 \cdot 843 \\ \text { rpL17 (liver) } & 1 \cdot 973 \\ & 1.996 \\ \text { Efficiency=10e }(-1 / a) ; a \text {, slope of the standard curve. }\end{array}$

Pituitary prl mRNA expression dramatically increased after acclimation of sea bass to FW. In terms of number of copies per microgram RNA (Fig. 1), the expression level of prl in FW fish was $4 \cdot 5$-fold higher $(P<0 \cdot 0001)$ compared with SW fish (about 30 millions copies in SW and 136 millions copies in FW). Relative to rpL17 or ef1 $\alpha$, prl expression was significantly lower $(P<0 \cdot 0001)$ in SW fish than in FW fish (Table 3). The prl gene had the second highest transcriptional level in FW fish, after POMC (in FW and SW fish, see below) compared with the other target genes (Fig. 1).

The number of copies of gh per microgram RNA also tended to be increased in pituitary gland of FW fish (1.9-fold higher than in SW fish; Fig. 1), but this difference was just not statistically significant, neither for the number of copies, nor for the expression relative to rpL17 or ef1 $\alpha$ (Table 3). Expression of igfl mRNA in liver did not significantly differ between FW and SW sea bass (Table 3). The number of copies per microgram RNA of this hormone mRNA in the liver was very low in both SW and FW conditions ( $325 \pm 57$ and $408 \pm 47$ respectively).

Pituitary sl mRNA expression significantly decreased after acclimation of sea bass to FW. The number of copies per microgram RNA in FW fish (10 $326914 \pm 920540$ ) was $1 \cdot 8$-fold lower $(P<0 \cdot 05)$ compared with SW fish (18 $709872 \pm 3499$ 884) (Fig. 1). The mRNA expression relative to rpL17 or ef1 $\alpha$ of SW and FW fish was also significantly different $(P<0 \cdot 05$; Table 3$)$.

Expression levels of pomc mRNA were similar in FW and SW sea bass (Table 3). The number of copies per microgram RNA of this prohormone in the pituitary of SW and FW fish was very high (about 250 millions copies); the abundance of this prohormone was much higher than any of the other target genes tested (Fig. 1). Expression of gthI and gthII mRNA in the pituitary gland also did not significantly differ between sea bass in FW or SW (Table 3). In terms of number of copies per microgram RNA, mean mRNA expression level of gthI in SW fish was $2 \cdot 1$-fold lower compared with $\mathrm{FW}$, but there was no statistically significant difference (Fig. 1). 


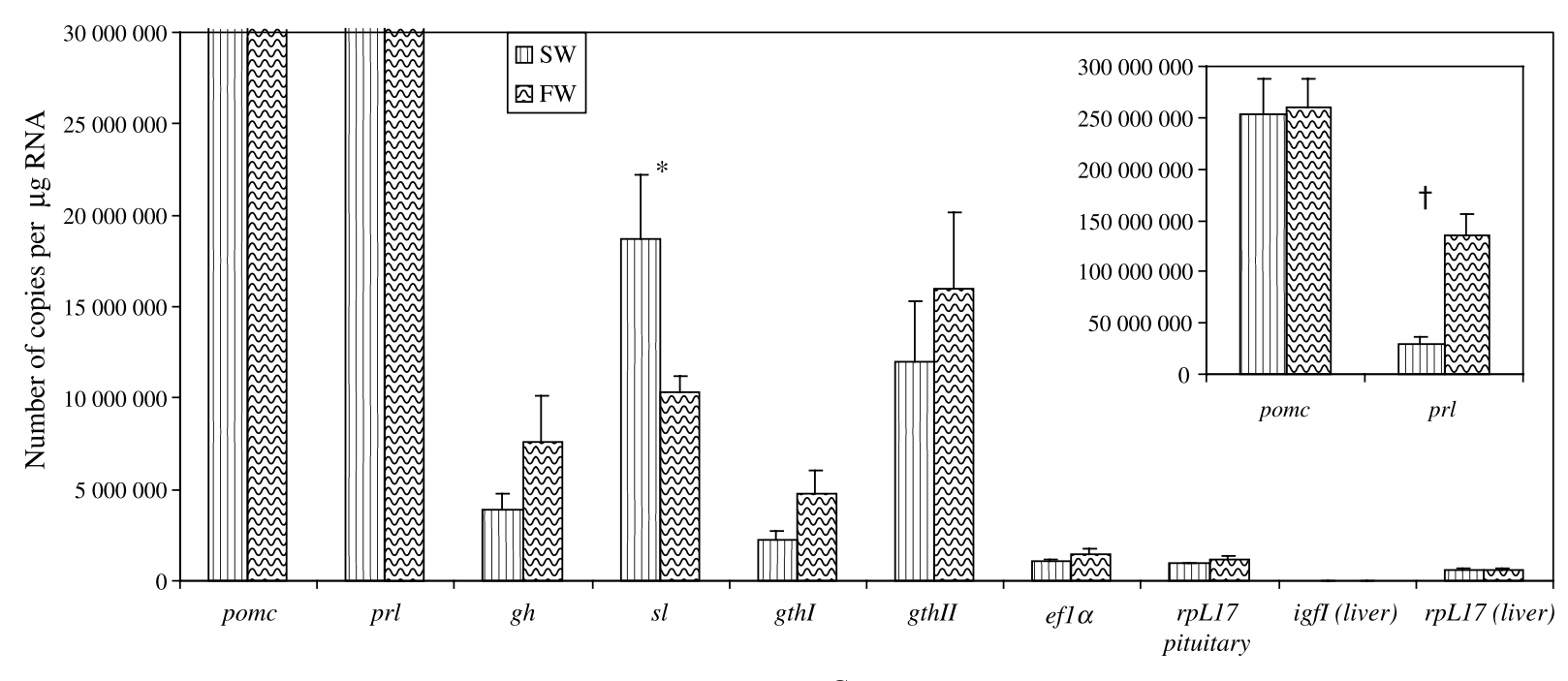

Genes

Figure 1 Number of copies per microgram total RNA of pituitary prl, gh, sl, pomc, gthl, gthll, rpL17, ef1 $\alpha$, and of liver igfl, rpL17 (mean \pm s.D.; $n=8-10)$, in sea bass (Dicentrarchus labrax) maintained in SW (35\%o) or adapted for 1 month in FW $(0 \cdot 3 \%$ ). Symbols indicate significant differences between the two salinity conditions, ${ }^{*} P<0 \cdot 05,{ }^{+} P<0 \cdot 0001$.

Plasma cortisol levels were $6 \cdot 5$-fold lower $(P<0 \cdot 001)$ in SW- than in FW-adapted specimens $(4 \cdot 0 \pm 1 \cdot 9$ and $26 \cdot 0 \pm$ $8 \cdot 5 \mathrm{nM}$ respectively).

Gill $\mathrm{Na}^{+} / \mathrm{K}^{+}$-ATPase-specific activity was $2 \cdot 3$-fold higher in FW than in SW: it was $7 \cdot 00 \pm 0 \cdot 71$ and $3 \cdot 03 \pm$ $0.56 \mu \mathrm{mol} \mathrm{P}_{\mathrm{i}} / \mathrm{h}$ per $\mathrm{mg}$ protein respectively.

\section{Discussion}

The aim of this study was to quantitatively compare mRNA levels of pituitary hormones in sea bass kept in FW or SW, by measuring mRNA levels by real-time PCR. Although this technique has become one of the most appropriate ways to detect and quantify mRNA expression, normalization is necessary at different steps of its implementation to ensure data reliability and consistency (Bustin et al. 2005). We first normalized the rate of the RT by introducing an 'alien' gene, i.e. CAB (see Materials and Methods section). To quantify the level of mRNA expression of a target gene, it is also necessary to measure the expression level of a constitutively transcribed house-keeping gene treated identically as the target gene prior to measurements. However, significant differences may exist (up to tenfold) in the expression levels of endogenous reference genes that have commonly been used to normalize mRNA expression

Table 3 Hormone mRNA expression (mean \pm s.D.; $n=8-10)$ in sea bass (Dicentrarchus labrax) maintained in SW $(35 \%$ or or adapted for one month to FW $(0 \cdot 3 \%)$

\begin{tabular}{|c|c|c|c|c|c|}
\hline & Salinity & $\begin{array}{l}\text { Relative to } L 17 \\
\text { mRNA expression }\end{array}$ & $\boldsymbol{P}$ & $\begin{array}{l}\text { Relative to ef } 1 \alpha \\
\text { mRNA expression }\end{array}$ & $\boldsymbol{P}$ \\
\hline \multicolumn{6}{|l|}{ Hormone } \\
\hline & SW & $1 \cdot 30 \pm 0 \cdot 03$ & $<0 \cdot 0001$ & $1 \cdot 22 \pm 0 \cdot 02$ & $<0 \cdot 0001$ \\
\hline & FW & $1 \cdot 50 \pm 0.02$ & & $1 \cdot 40 \pm 0.01$ & \\
\hline \multirow[t]{2}{*}{$g h$} & SW & $1 \cdot 16 \pm 0.02$ & $0 \cdot 37$ & $1 \cdot 09 \pm 0.02$ & $0 \cdot 42$ \\
\hline & FW & $1 \cdot 20 \pm 0.02$ & & $1 \cdot 11 \pm 0 \cdot 02$ & \\
\hline \multirow[t]{2}{*}{ sl } & SW & $1 \cdot 27 \pm 0.02$ & $<0 \cdot 05$ & $1 \cdot 20 \pm 0 \cdot 02$ & $<0 \cdot 05$ \\
\hline & FW & $1 \cdot 20 \pm 0 \cdot 01$ & & $1 \cdot 12 \pm 0.02$ & \\
\hline \multirow[t]{2}{*}{ pomc } & SW & $1.51 \pm 0.03$ & $0 \cdot 81$ & $1 \cdot 42 \pm 0.02$ & $0 \cdot 64$ \\
\hline & FW & $1 \cdot 50 \pm 0.03$ & & $1 \cdot 40 \pm 0.03$ & \\
\hline \multirow[t]{2}{*}{ gthl } & SW & $1 \cdot 11 \pm 0 \cdot 03$ & $0 \cdot 20$ & $1 \cdot 04 \pm 0.03$ & $0 \cdot 24$ \\
\hline & FW & $1 \cdot 17 \pm 0.03$ & & $1 \cdot 09 \pm 0.03$ & \\
\hline \multirow[t]{2}{*}{ gthll } & SW & $1 \cdot 12 \pm 0.05$ & $0 \cdot 50$ & $1 \cdot 05 \pm 0 \cdot 05$ & $0 \cdot 57$ \\
\hline & FW & $1 \cdot 17 \pm 0 \cdot 03$ & & $1 \cdot 09 \pm 0 \cdot 04$ & \\
\hline \multirow[t]{2}{*}{ igfl (liver) } & SW & $0 \cdot 61 \pm 0 \cdot 003$ & $0 \cdot 24$ & - & \\
\hline & FW & $0 \cdot 62 \pm 0 \cdot 004$ & & - & \\
\hline
\end{tabular}

For each hormone, mRNA expression has been normalized on the expression of the alien gene and is expressed in values relative to the expression of the house keeping genes. 
of target genes (Bustin 2000). There is increasing evidence that genes encoding structural ribosomal proteins or translation factors are among the genes with the lowest transcriptional regulation (Gray \& Wickens 1998, Frost \& Nilsen 2003). In the present study, we demonstrate that expression levels of rpL17 and ef1 $\alpha$ did not vary between SW and FW sea bass (D. labrax); these genes were consequently considered suitable for internal calibration of real-time PCR data in this species. Since co-regulation of rpL17 (structural component of the ribosome) and of ef $1 \alpha$ (involved in translation) seems unlikely, the use of both as reference genes should make quantification completely reliable.

Considering the precautions mentioned above, our data more accurately compare mRNA expression of genes between experimental conditions (the main thrust of this work) and to a lesser degree estimate differences in mRNA expression between genes within individuals. We focused on the comparison of pituitary hormone mRNA synthesis under two steady-state conditions, proceeding from the notion that significant differences in the gene expression must correspond to anticipated and well-known differences in protein productions and secretion.

The eventual physiological interpretation of the protein output of cells requires aspects such as differential storage and post-translational processing, phenomena we did not address here. However, this study is unique as it is the first to address absolute mRNA quantification of European sea bass hormone genes by real-time quantitative PCR. Most studies so far and mentioned below concern data on hormone mRNA expression in fishes obtained by means of semiquantitative methods (blotting, RNAse protection assays) that allow only qualitative comparisons.

An interesting finding of the present study is the differential expression of sl mRNA in sea bass in SW and FW. To the best of our knowledge, this is the first report on a putative role of pituitary sl in teleost osmoregulation. Sl is a recently (early 1990s of the former century) discovered member of the gh/prl family, produced in the pituitary pars intermedia (Ono et al. 1990). Most of the studies published on sl concern only a single group of fish, viz. salmonids, and although these studies highlight the pleiotropic character of the hormone (Ono \& Kawauchi 1994, Kakizawa et al. 1997, Pérez-Sanchez et al. 2002), still little is known on sl physiology. Although a second $s l$ gene has been recently found in zebrafish (Zhu et al. 2004), in sea bass as well as in most of the studied species, only one $s$ gene has been reported to date (Company et al. 2000). We report here that pituitary mRNA level of this hormone was significantly higher $(1 \cdot 8$-fold) in SW than FW sea bass. Down-regulation of sl mRNA in FW suggests an involvement in hyposmotic regulation in this species.

$\mathrm{Prl}$ and gh, the two other members of the pleiotropic $\mathrm{sl} / \mathrm{prl} / \mathrm{gh}$ gene family, appear to antagonize each other in salinity adaptation (reviews in McCormick 2001, Manzon 2002). Indeed, in sea bass too, pituitary prl mRNA increased $4 \cdot 5$-fold in FW sea bass compared with SW, congruent with the established key role of this hormone in hyperosmotic regulation.
Remarkably, in both FW and SW, prl mRNA levels were relatively higher than the mRNA expression of most other genes quantified in this work, which probably underlines the wide range of biological activities of this hormone (Björnsson et al. 2002, Pérez-Sanchez et al. 2002) and a particular role for prl in SW sea bass. Although the role of prl in FW adaptation varies among species, it is well established as the hormone preventing loss of ions (particularly $\mathrm{Na}^{+}$and $\mathrm{Cl}^{-}$) and decreasing integumental permeability to water of osmoregulatory organs in euryhaline teleosts (reviews in Hirano et al. 1987, Manzon 2002). A good correlation between prl mRNA expression in the pituitary and prl plasma concentration has been shown in Atlantic salmon Salmo salar, since both are elevated during smoltification and decrease after entry of completely smoltified fish in SW (Bœuf 1993, Agùstsson et al. 2003). Moreover, both mRNA levels and plasma protein decrease after transfer from FW to isosmotic (brackish) water in channel catfish Ictalurus punctatus (Tang et al. 2001) as well as in the tilapia Oreochromis niloticus (Auperin et al. 1994). Our results show that increased pituitary prl levels are part of the osmoregulatory strategy in FW adaptation of sea bass.

In salmonid species, prl may antagonize the SW-adaptive actions of gh (Sakamoto et al. 1993, McCormick 1995, Seidelin \& Madsen 1997). Some (if not all) of the osmoregulatory effects of gh are mediated by igfl which is known, indeed, to interact with both prl and gh (Mancera \& McCormick 1998, Fruchtman et al. 2001, Kajimura et al. 2002, Pérez-Sanchez et al. 2002). We found no significant difference either in sea bass pituitary gh mRNA level, or in liver igfl mRNA expression, whether the fish were in FW or SW. Yet, unaffected pituitary gh or liver igfl mRNA levels in SW and FW were also reported for the euryhaline Mozambique tilapia Oreochromis mossambicus (Ayson et al. 1994) and the rainbow trout Oncorhynchus mykiss (Sakamoto \& Hirano 1993), which could indicate that the SW-adaptive actions of gh/igfl are particular to parr-smolt transformation of salmonids. Interestingly, the pituitary gh mRNA level (mean value) was about twofold higher in FW sea bass, and although the difference was not statistically significant because of the high variability between samples, it is a response to FW adaptation different to what one would predict from salmonid responses. In Mozambique tilapia, Riley et al. (2003) postulated that transfer from SW to FW could activate the gh/igfl axis. Absence of significant differences in gh and igfl mRNA expression does not allow to conclude that these hormones are not involved in sea bass osmoregulation. It is very likely that in this species when in FW or SW, metabolic clearance and distribution space for gh and igfl differ, but we do not know how these processes and properties relate to mRNA expression, nor how the kinetics of the activation/deactivation of the gh/igfl axis are during salinity challenges.

Prl and gh plus igfl, interact with cortisol, widely considered the SW-adapting hormone (reviews in Sakamoto et al. 1993, McCormick 1995). Interestingly, plasma cortisol levels were higher in FW-adapted than in SW maintained sea bass specimens. The endocrine control of cortisol secretion in 
teleosts is dominated by the pituitary gland, in particular by acth and $\alpha$-msh plus $\beta$-endorphin (reviews in Mayer-Gostan et al. 1987, Wendelaar Bonga 1997). These peptides are derived from the same precursor, pomc. In sea bass, no difference was found in pituitary pomc mRNA level in SW or FW fish. In accordance with a previous study (Varsamos et al. 2003), pituitary pomc mRNA levels are very high $(2-3 \times$ $10^{8}$ copies/ $\mu$ g RNA) under both water salinity conditions. Unfortunately, we did not discriminate between pituitary pars distalis (acth cells) and pars intermedia (msh cells), as the small acth cell volume did not allow the anticipated analyses. Obviously, differences in acth-cell pomc mRNA expression in FW and SW fish may have gone undetected in our set up, and this aspect requires further experimentation.

There is some evidence for a complex interaction between the gnrh-gth sex-steroid axis and the gh/igfl axis, given a demonstrated role of gh in salmonid reproduction (Björnsson et al. 2002). Moreover, sex maturation and treatment with sex steroids is known to affect SW adaptation of some species (McCormick 1995, Riley et al. 2002). Our findings concerning pituitary gth mRNA expression do not substantiate an involvement of these hormones in salinity adaptation. Although sea bass can live and grow in FW, it neither does nor can reproduce in FW (Pickett \& Pawson 1994). Moreover, our fish may be considered sexually immature, which further precludes differences in expression of these genes. More investigations on salinity effect on gonad maturation and/or on a putative role of reproductive hormones in osmoregulation will be necessary.

Branchial $\mathrm{Na}^{+} / \mathrm{K}^{+}$-ATPase activity was $2 \cdot 3$-fold higher in FW sea bass compared with SW fish. We (Varsamos et al. $2002 a, b)$ have demonstrated that the euryhalinity of this species relies in part on the phenotypic plasticity of branchial ionocytes, also called mitochondria rich cells (MRC) and their $\mathrm{Na}^{+}$/ $\mathrm{K}^{+}$-ATPase content that differs drastically between FWand SW. $\mathrm{Prl}$, gh, igfl, and cortisol are known to affect MRC number and size as well as $\mathrm{Na}^{+} / \mathrm{K}^{+}$-ATPase activity throughout the postembryonic development of teleosts (reviews in McCormick 2001, Sakamoto et al. 2001, Varsamos et al. 2005). Clearly, the sea bass endocrine osmoregulatory repertoire differs from that of most other teleosts studied so far. Following transfer from SW to FW, numbers and size of MRCs increase, as does $\mathrm{Na}^{+} / \mathrm{K}^{+}$ATPase activity, concomitantly with elevated prl expression and plasma cortisol levels. This is counterintuitive to the welldocumented inhibitory actions of prl on these cells and this enzyme in other euryhaline teleosts (Flik et al. 1994, Manzon 2002). Moreover, sl appears to be implicated in sea bass osmoregulation, prompting further investigations on this hormone in teleost salinity adaptation. At last, our results do not allow the exclusion of a putative involvement of gh in FW adaptation of this species. The present study thus constitutes a first step towards the assessment of pituitary hormonal messengers involved in control of osmoregulation in the European sea bass D. labrax. More work is needed on hormone expression and/or concentrations of the proteins of these hormones in plasma and tissues, especially for prl, gh, and sl. For the mRNAs involved we now have a starting point of view.

\section{Acknowledgements}

Authors would like to thank Dr F Bonhomme for hosting our experiments in the aquaculture facilities of the Station Biologique de Sète (Hérault, France), as well as Mr M Cantou and Mr L Libitz for fish husbandry. The authors declare that there is no conflict of interest that would prejudice the impartiality of this scientific work.

\section{References}

Agùstsson T, Sundell K, Sakamoto T, Ando M \& Björnsson BT 2003 Pituitary gene expression of somatolactin, prolactin, and growth hormone during Atlantic salmon parr-smolt transformation. Aquaculture 222 229-238.

Arends RJ, van der Gaag R, Martens GJM, Wendelaar Bonga SE \& Flik G 1998 Differential expression of two pro-opiomelanocortin mRNAs during temperature stress in common carp (Cyprinus carpio L.). Journal of Endocrinology 159 85-91.

Auperin B, Rentier-Delrue F, Martial JA \& Prunet P 1994 Evidence that two tilapia (Oreochromis niloticus) prolactins have different osmoregulatory functions during adaptation to a hyperosmotic environment. Journal of Molecular Endocrinology 12 13-24.

Ayson FG, Kaneko T, Hasegawa S \& Hirano T 1994 Differential expression of two prolactin and growth hormone genes during early development of tilapia (Oreochromis mossambicus) in freshwater and seawater: implications for possible involvement in osmoregulation. General and Comparative Endocrinology 95 143-152.

Björnsson BT, Johansson V, Benedet S, Einarsdottir IE, Hildahl J, Agùstsson T \& Jönsson E 2002 Growth hormone endocrinology of salmonids: regulatory mechanisms and mode of action. Fish Physiology and Biochemistry 27 227-242.

Bœuf G 1993 Salmonid smolting: a pre-adaptation to the oceanic environment. In Fish Ecophysiology, vol 9, pp 105-136. Eds JC Rankin \& FB Jensen. London: Chapman and Hall.

Bustin SA 2000 Absolute quantification of mRNA using real-time reverse transcription polymerase chain reaction assays. Journal of Molecular Endocrinology 25 169-193.

Bustin SA, Benes V, Nolan T \& Pfaffl MW 2005 Quantitative real-time RT-PCR - a perspective. Journal of Molecular Endocrinology 34 597-601.

Company R, Calduch-Giner JA, Mingarro M \& Perez-Sanchez J 2000 cDNA cloning and sequence of European sea bass (Dicentrarchus labrax) somatolactin. Comparative Biochemistry and Physiology B Comparative Biochemistry 127 183-192.

Doliana R, Bortolussi M \& Colombo L 1992 Cloning and sequencing of European sea bass (Dicentrarchus labrax L.) growth hormone cDNA using polymerase chain reaction and degenerate oligonucleotides. DNA Sequence 3 185-189.

Doliana R, Argentini C, Segat D, Santarossa P, Mucignat MT, Colombo L \& Bortolussi M 1994 The prolactin of European sea bass (Dicentrarchus labrax L.): cloning of cDNA and efficient expression in Escherichia coli. Biochemistry and Molecular Biology International 33 1117-1126.

Flik G, Wendelaar Bonga SE \& Fenwich JC $1983 \mathrm{Ca}^{2+}$-dependent phosphatase and ATPase activities in eel gill plasma membranes-I. Identification of $\mathrm{Ca}^{2+}$-activated ATPase activities with non-specific phosphatase activities. Comparative Biochemistry and Physiology. B, Comparative Biochemistry 76 745-754.

Flik G, Rentier-Delrue F \& Wendelaar Bonga SE 1994 Calcitropic effects of recombinant prolactins in Oreochromis mossambicus. American Journal of Physiology. Regulatory Integrative and Comparative Physiology 266 R1302-R1308.

Frost P \& Nilsen F 2003 Validation of reference genes for transcription profiling in the salmon louse, Lepeophtheirus salmonis, by quantitative real-time PCR. Veterinary Parasitology 118 169-174. 
Fruchtman S, Gift B, Howes B \& Borski R 2001 Insulin-like growth factor-I augments prolactin and inhibits growth hormone release through distinct as well as overlapping cellular signaling pathways. Comparative Biochemistry and Physiology. B, Comparative Biochemistry 129 237-242.

Fuentes J \& Eddy FB 1997 Drinking in marine, euryhaline and freshwater teleost fish. In Ionic Regulation in Animals, pp 135-149. Eds N Hazon, FB Eddy \& G Flik. Heidelberg: Springer.

Gray NK \& Wickens M 1998 Control of translation initiation in animals. Annual Review of Cell and Developmental Biology 14 399-458.

Hirano T, Ogasawara T, Bolton JP, Collie NL, Hasegawa S \& Iwata M 1987 Osmoregulatory role of prolactin in lower vertebrates. In Comparative Physiology of Environmental Adaptations, vol 1, pp 112-124. Eds R Kirsch \& B Lahlou. Basel: Karger.

Kajimura S, Uchida K, Yada T, Hirano T, Aida K \& Grau EG 2002 Effects of insulin-like growth factors (IGF-I and -II) on growth hormone and prolactin release and gene expression in euryhaline tilapia, Oreochromis mossambicus. General and Comparative Endocrinology 127 223-231.

Kakizawa D, Ishimatsu A, Takeda T, Kaneko T \& Hirano T 1997 Possible involvement of somatolactin in the regulation of plasma bicarbonate for the compensation of acidosis in rainbow trout. Journal of Experimental Biology $2002675-2683$.

Mancera MJ \& McCormick SD 1998 Osmoregulatory actions of the GH/IGF axis in non-salmonid teleosts. Comparative Biochemistry and Physiology. B, Comparative Biochemistry 121 43-48.

Manzon LA 2002 The role of prolactin in fish osmoregulation: a review. General and Comparative Endocrinology 125 291-310.

Marshall WS 1995 Transport processes in isolated teleost epithelia: opercular epithelium and urinary bladder. In Cellular and Molecular Approaches to Fish Ionic Regulation, vol 14, pp 1-19. Eds CM Wood \& TJ Shuttleworth. London: Academic Press.

Mateos J, Mananos E, Martinez-Rodriguez G, Carrillo M, Querat B \& Zanuy S 2003 Molecular characterization of sea bass gonadotropin subunits (alpha, FSHbeta, and LHbeta) and their expression during the reproductive cycle. General and Comparative Endocrinology 133 216-232.

Mayer-Gostan N, Wendelaar Bonga SE \& Balm PHM 1987 Mechanisms of hormone actions on gill transport. In Vertebrate Endocrinology: Fundamentals and Biomedical Implications, vol 2, pp 211-230. Ed. PKT Pang. New-York: Academic Press.

McCormick SD 1995 Hormonal control of gill $\mathrm{Na}^{+}, \mathrm{K}^{+}$-ATPase and chloride cell function. In Cellular and Molecular Approaches to Fish Ionic Regulation, vol 14, pp 285-307. Eds CM Wood \& TJ Shuttleworth. London: Academic Press.

McCormick SD 2001 Endocrine control of osmoregulation in teleost fish. American Zoologist 41 781-794.

Ono M \& Kawauchi H 1994 The somatolactin gene. In Molecular Endocrinology of Fish, vol 13, pp 159-177. Eds NM Sherwood \& CL Hew. London: Academic Press.

Ono M, Takayama Y, Rand-Weaver M, Sakata S, Yasunaga T, Noso T \& Kawauchi H 1990 cDNA cloning of somatolactin, a pituitary protein related to gowth hormone and prolactin. PNAS 87 4330-4334.

Pérez-Sanchez J, Calduch-Giner J, Mingarro M, Vega-Rubin de Celis S, Gomez-Requeni P, Saera-Vila A, Astola A \& Valdivia M 2002 Overview of fish growth hormone family. New insights in genomic organization and heterogeneity of growth hormone receptors. Fish Physiology and Biochemistry 27 243-258.

Pickett GD \& Pawson MG 1994 In Sea Bass: Biology, Exploitation and Conservation, pp 177-337. Ed. TJ Pitcher. London: Chapman and Hall.

Pisam M \& Rambourg A 1991 Mitochondria-rich cells in the gill epithelium of teleost fishes: an ultrastructural approach. International Review of Cytology 130 191-232.

Plisetskaya EM 1998 Some of my not so favourite things about insulin and insulin-like growth factors in fish. Comparative Biochemistry and Physiology. B, Comparative Biochemistry 121 3-11.

Rasmussen R 2001 Quantification on the light cycler. In Rapid Cycle Real-Time PCR: Methods and Applications, pp 21-34. Eds S Meuer, C Wittwer \& K Nakagawara. Berlin, Heidelberg: Springer-Verlag.
Riley L, Richman N, III., Hirano T \& Grau EG 2002 Activation of the growth hormone/insulin-like growth factor axis by treatment with 17 alpha-methyltestosterone and seawater rearing in the tilapia, Oreochromis mossambicus. General and Comparative Endocrinology 127 285-292.

Riley L, Hirano T \& Grau EG 2003 Effects of transfer from seawater to fresh water on the growth hormone/insulin-like growth factor-I axis and prolactin in the Tilapia, Oreochromis mossambicus. Comparative Biochemistry and Physiology. B, Comparative Biochemistry 136 647-655.

Sakamoto T \& Hirano T 1993 Expression of insulin-like growth factor I gene in osmoregulatory organs during seawater adaptation of the salmonid fish: possible mode of osmoregulatory action of growth hormone. PNAS 90 1912-1916.

Sakamoto T, McCormick SD \& Hirano T 1993 Osmoregulatory actions of growth hormone and its mode of action in salmonids: a review. Fish Physiology and Biochemistry 11 1-6.

Sakamoto T, Uchida K \& Yokota S 2001 Regulation of the ion-transporting mitochondrion-rich cell during adaptation of teleost fishes to different salinites. Zoological Science 18 1163-1174.

Seidelin M \& Madsen SS 1997 Prolactin antagonizes the seawater-adaptive effect of cortisol and growth hormone in anadromous brown trout (Salmo trutta). Zoological Science 14 249-256.

Tang Y, Shepherd BS, Nichols AJ, Dunham R \& Chen TT 2001 Influence of environmental salinity on messenger RNA levels of growth hormone, prolactin, and somatolactin in pituitary of the channel catfish (Ictalurus punctatus). Marine Biotechnology 3 205-217.

Varlet-Marie E, Audran M, Lejeune M, Bonafoux B, Sicart MT, Marti J, Piquemal D \& Commes T 2004 Analysis of human reticulocyte genes reveals altered erythropoiesis: potential use to detect recombinant human erythropoietin doping. Haematologica 89 991-997.

Varsamos S 2002 Tolerance range and osmoregulation in hypersaline conditions in the European sea bass (Dicentrarchus labrax). Journal of the Marine Biological Association of the UK 82 1047-1048.

Varsamos S, Connes R, Diaz JP, Barnabé G \& Charmantier G 2001 Ontogeny of osmoregulation in the European sea bass Dicentrarchus labrax L. Marine Biology 138 909-915.

Varsamos S, DiazJP, Charmantier G, Blasco C, Connes R \& Flik G 2002a Location and morphology of chloride cells during the postembryonic development of the European sea bass, Dicentrarchus labrax. Anatomy Embryology 205 203-213.

Varsamos S, Diaz JP, Charmantier G, Flik G, Blasco C \& Connes R $2002 b$ Branchial chloride cells in sea bass (Dicentrarchus labrax) adapted to freshwater, seawater and doubly-concentrated seawater. Journal of Experimental Zoology 293 12-26.

Varsamos S, Wendelaar Bonga SE, Flik G, Queré R \& Commes T 2003 Cloning of a proopiomelanocortin cDNA from the pitutitary gland of the sea bass (Dicentrarchus labrax) and assessment of mRNA expression in different tissues by means of real-time PCR. Journal of Endocrinology 176 405-414.

Varsamos S, Wendelaar Bonga SE, Charmantier G \& Flik G 2004 Drinking rates and $\mathrm{Na}^{+} / \mathrm{K}^{+}$ATPase during the early development of the European sea bass Dicentrarchus labrax: ontogeny and variation following acute salinity changes. Journal of Experimental Marine Biology and Ecology 311 189-200.

Varsamos S, Nebel C \& Charmantier G 2005 Ontogeny of osmoregulation in postembryonic fish: a review. Comparative Biochemistry and Physiology. A, Comparative Physiology 141 401-429.

Wendelaar Bonga SE 1997 The stress response in fish. Physiological Reviews 77 591-625.

Zaugg WS 1982 A simplified preparation for adenosine triphosphatase determination in gill tissue. Canadian Journal of Fisheries and Aquatic Sciences 39 215-217.

Zhu Y, Stiller JW, Shaner MP, Baldini A, Scemama1 JL \& Capehart AA 2004 Cloning of somatolactin $\alpha$ and $\beta$ cDNAs in zebrafish and phylogenetic analysis of two distinct somatolactin subtypes in fish. Journal of Endocrinology 182 509-518.

Received in final form 11 July 2006

Accepted 28 July 2006

Made available online as an Accepted Preprint 25 August 2006 